\title{
Quality characteristics of vinegar fermented with different amounts of black garlic and alcohol
}

\author{
Weon Tack Seo ${ }^{1}$, Myoung Hyo Choi ${ }^{2}$, Hye Jin $\mathrm{Sim}^{2}$, Gyeong Wha Kim², \\ Yeon Mi Shin ${ }^{1}$, Min Jung Kang ${ }^{2 *}$ \\ ${ }^{1}$ Department of Food Science, Gyeongnam National University of Science and Technology, Jinju 52725, Korea \\ ${ }^{2}$ Namhae Garlic Research Institute, Namhae 52430, Korea
}

\section{흑마늘의 첨가량과 초기 알코올 농도를 달리한 발효 식초의 품질특성}

\author{
서원택 $^{1} \cdot$ 최명효 $^{2} \cdot$ 심혜진 $^{2} \cdot$ 김경화 $^{2} \cdot$ 신연미 $^{1} \cdot$ 강민정 $^{2 *}$ \\ ${ }^{1}$ 경남과학기술대학교 식품과학부, ${ }^{2}$ 남해마늘연구소
}

\begin{abstract}
The quality characteristics of black garlic vinegar produced by acetic acid fermentation were analyzed over a 25 day period. Black garlic vinegar was produced using black garlic 3, 6, 9 and 12 folds with water, and initial alcohol concentrations of $6 \sim 12 \%$. The $\mathrm{pH}$ values of the vinegar samples were in range of $3.85 \sim 4.46$ after 25 days fermentation, and the sugar contents were highest after 9 days of fermentation (12.00 13.50 ${ }^{\circ}$ Brix $)$. The total polyphenol concents of vinegars were in the range of $20.65 \sim 52.04 \mathrm{mg} / 100 \mathrm{~mL} 25$ days fermentation. Pyrogallol and vanillic acid were detected in the completely fermented vinegars, and their contents increased with black garlic content. Five organic acids (lactic acid, acetic acid, citric acid, succinic acid and propionic acid) were detected after 25 days of fermentation, with the total amount of organic acids being 5,327.34 6,307.64 mg/100 mL, and the total abetic acid contents beging the highest of the organic acids at 4208.90 5,570.29 mg/100 mL. After 25 days of fermentation, the total minerals contents were higher, and depending on the quantity of black garlic added. Of the minerals, the of potassium content was the highest $(366.23 \sim 1,619.67 \mathrm{mg} / \mathrm{L})$.
\end{abstract}

Key words : vinegar, black garlic, organic acid, phenolic compound, S-allyl cysteine

\section{서 론}

식초는 당이나 전분질을 함유하고 있는 과일, 곡류 등을 원료로 하여 효모에 의해 당이 알코올로 발효되고, 초산균 에 의해 알코올이 초산으로 산화되는 2 단계의 발효공정을 거쳐 제조된다(1). 식초에는 신맛을 내는 초산성분을 비롯 하여 유기산, 아미노산, 당류, 염류 및 각종 영양물질이 함유 되어 있고, 향기 성분에는 원료에 따른 여러 가지 에스테르 류의 방향성 물질이 작용한다(2). 또한 식초는 단맛, 짠맛

*Corresponding author. E-mail : jung-75@hanmail.net Phone : 82-55-860-8952, Fax : 82-55-860-8960

Received 17 October 2015; Revised 19 November 2015; Accepted 14 December 2015.

Copyright (c) The Korean Society of Food Preservation. All rights reserved.
등과 조화를 이루어 음식 맛을 부드럽게 하고 특유의 향미 를 더해주며 육류의 연화작용 및 생선의 비린내 감소 등의 기능이 있어 조리에 다양하게 이용되고 있다(3).

식초의 종류에는 알코올 및 당류를 원료로 한 알코올식 초, 과실 착즙액을 사용한 과실식초, 곡물을 사용한 곡물식 초 등이 있는데, 알코올 식초는 주정초라고도 하며 총산도 $12 \%$ 이상의 고산도 식초가 여기에 해당되며, 과실식초는 과즙을 $30 \%$ 이상 첨가한 감식초, 귤초 등이 있고, 곡물을 $4 \%$ 이상 함유하고 있는 곡물식초가 있다(4).

식초에는 다양한 재료들이 사용되고 있어 식초 자체의 기능성과 더불어 첨가되는 부재료로부터 기인하는 기능성 이 향상된 식초의 개발과 관련한 연구결과들이 보고되고 있다. 그 예로서 Ann 등(5)은 홍삼식초 섭취 시 체중을 감소 시켜 비만 억제 효과가 있다고 하였으며, 감식초는 혈중 $\mathrm{LDL}$ 콜레스테롤을 낮추고, $\mathrm{HDL}$ 콜레스테롤을 상승시키 
며, 간과 근육에 함유되어 있는 glycogen을 증가시켜 운동 기능성 증대에 효과가 있다(6). 미나리 식초의 acetic acid는 $\mathrm{TCA}$ 회로의 활성화를 도와 젖산분해를 촉진하고, aspartic acid는 피로 회복 효과를 지닌다(2). 무화과 식초는 gammaamino butyric acid(GABA) 함량이 높아 성인병 예방과 청소 년기의 학습능력 증진 효과(7)가 있으며, 오이식초는 혈장 acetaldehyde 농도를 낮추어 숙취 해소 효과가 있는 것으로 보고되어 있다(8).

마늘(Allium sativum L.)은 양파, 부추와 같은 백합과 (Lilliaceae)의 Allium에 속하는 다년초 작물로, 원산지는 서 부아시아 또는 중앙아시아로서 고대에 이미 지중해 연안까 지 전파되었고, 우리나라에는 중국을 통해서 전래된 것으 로 알려져 있다(9). 우리나라에서 재배되고 있는 마늘은 추운 지역에서 재배되는 한지형과 기온이 높은 지역에서 재배되는 난지형으로 구분할 수 있는데, 한지형은 삼척, 서산, 의성 등이 주산지이고, 난지형의 주산지는 남해, 제주, 해남 등으로 알려져 있다(10). 마늘은 면역증강, 항산화와 항균활성 등의 생리기능성이 보고되어 있고(11-13), 알린, 알리신, 사포닌, 플라보노이드 등의 다양한 생리활성 물질 들을 함유하고 있다(14).

마늘을 숙성 가공한 흑마늘은 주요 물질로 페놀성 화합 물, 갈변물질 및 S-allyl cysteine(SAC) 등을 함유하고 있으 며 혈중 콜레스테롤 저하, 암 예방, 심장질환의 예방, 동맥경 화 개선 등의 기능성을 가지고 있다(15-17). 흑마늘을 이용 한 제품으로는 흑마늘 추출액을 첨가한 와인(18), 흑마늘 페이스트를 첨가한 양갱(19), 흑마늘 추출물을 첨가한 두부 (20), 흑마늘을 첨가한 청국장(21) 등이 보고되어 있다. 이러 한 연구에도 불구하고, 흑마늘의 강한 색과 특유의 맛으로 인해 여러 식품에 적용시키기 위한 연구는 아직도 미흡한 실정이며 특히, 흑마늘을 이용한 식초 제조를 위한 연구 및 품질특성과 관련한 연구는 아직 보고된 바 없다. 이에 본 연구에서는 흑마늘의 첨가량을 달리하여 물과 함께 혼합 하고 여기에 동일한 양의 설탕으로 보당하여 알코올 발효 시킨 후 초산 발효 기간에 따른 품질관련 인자를 비교함으 로써 흑마늘 식초 제조를 위한 기초자료를 확보하고자 하였 다.

\section{재료 및 방법}

\section{흑마늘 식초의 제조}

원료 흑마늘은 남해보물섬마늘영농조합법인에서 제공 받아 외피를 제거하여 사용하였다. 흑마늘과 물을 무게비 로 $1: 2,1: 5,1: 8,1: 11$ 의 비율로 혼합하여 분쇄한 후 알코올 발효를 돕기 위하여 시료 모두에 동일하게 흑마늘 분쇄액 $\mathrm{kg}$ 당 $140 \mathrm{~g}$ 의 설탕을 가해 보당하고 균일하게 혼합한 다음 $3.5 \mathrm{~kg}$ 씩을 $5 \mathrm{~L}$ 광구병에 담아 $121^{\circ} \mathrm{C}$ 에서 10 분간 멸균하였
다. 멸균 후 무균실에서 식힌 다음 미리 종 배양한 효모 (Saccharomyces cerevisiae)를 $2.5 \%$ 접종하여 $30^{\circ} \mathrm{C}$ 에서 알코 올 발효를 실시하였다. 알코올 발효 기간 동안 $1 \%$ 알코올을 함유하는 맥아추출액 배지에서 Acetobacter pasterianus 균 을 3 일간 종 배양하여 종초를 준비하였으며, 이를 각각의 알코올 발효가 완성된 흑마늘 혼합물에 $5 \%$ 씩 접종한 다음 충분히 혼합한 것을 0 일차 시료로 하여, $30^{\circ} \mathrm{C}$ 에서 숙성시키 면서 9,18 및 25 일에 시료를 취하였다.

\section{알코올 농도, $\mathrm{pH}$ 및 당도 측정}

알코올 발효된 시료 $50 \mathrm{~mL}$ 에 증류수 $100 \mathrm{~mL}$ 를 가하고 환류냉각기를 이용하여 수증기 증류한 증류액 $30 \mathrm{~mL}$ 에 다시 증류수를 가하여 $50 \mathrm{~mL}$ 로 만든 액을 시료액으로 하여 디지털 주정계(MT-830, Atago Co., Tokyo, Japan)를 이용하 여 알코올 농도를 측정하였다.

각각의 시료를 여과지로(filter paper No. 2, Advantec, Tokyo, Japan) 여과한 여액을 시료로 하여 $\mathrm{pH}$ meter(720, Thermo Orion, Waltham, MA, USA)를 이용하여 측정하였다. 당도는 시료액을 일정량 취하여 자동굴절당도계(PR-201 a, Atago, Tokyo, Japan)로 3회 이상 반복 측정하였다.

\section{총 폴리페놀 화합물 및 페놀화합물의 확인과 정량}

총 폴리페놀 화합물의 함량은 페놀성 물질인 phosphomolybdic acid와 반응하여 청색을 나타내는 원리로 Foiln-Denis 방법 (22)을 이용하였다. 여과지로 여과한 식초액 $1 \mathrm{~mL}$ 에 Foline-Ciocalteau 시약 $0.5 \mathrm{~mL}$ 를 넣고 3분 후 $10 \% \mathrm{Na}_{2} \mathrm{CO}_{3}$ 용액 $0.5 \mathrm{~mL}$ 씩을 가한 후 혼합하여 실온의 암실에서 1 시간 정치한 다음 분광광도계(Libra S 35, Biochrom, Cambridge, England)로 $760 \mathrm{~nm}$ 에서 흡광도를 측정하였다. 표준물질로 gallic acid(Sigma Chemical Co., St, Louis, MO, USA)를 사용 하여 시료와 동일한 방법으로 분석하여 얻은 검량선으로부 터 총 페놀 화합물의 함량을 계산하였다.

발효가 완료된 숙성 25 일차 식초를 시료로 하여 페놀화 합물을 확인 정량하고자 각각의 시료액을 일정량 취하여 $0.45 \mu \mathrm{m}$ membrane filter로 여과한 후 HPLC-DAD(Agilent 1260 infinity, Agilent, Santa Clara, CA, USA)로 분석하였다. 분석용 컬럼은 Zorbax SB-C $\mathrm{C}_{18}(4.6 \times 250 \mathrm{~mm}, 5 \mu \mathrm{m}$, Agilent Technologies, Palo Alto, CA, USA)를 사용하였고, 이동상 용매는 $0.1 \%$ formic acid 수용액과 acetonitrile에 용해한 $0.1 \%$ formic acid를 시간에 따라 혼합비율을 조절하면서 분석하였다. 이동상의 속도는 $0.7 \mathrm{~mL} / \mathrm{min}$, 시료 주입량은 $10 \mu \mathrm{L}, \mathrm{UV}$ 검출기의 파장은 $280 \mathrm{~nm}$ 에서 검출하였다. 페놀 화합물은 총 17 종의 표준물질을 동일한 조건에서 분석한 결과로부터 확인 및 정량하였다.

\section{S-allyl cysteine(SAC) 함량 분석}

각각의 시료를 여과지로 여과한 후 여액을 취하여 0.22 
$\mu \mathrm{m}$ membrane filter로 재여과하여 HPLC-PDA-MS/MS(TSQ Quantum LC-MS/MS, Thermo scientific, Waltham, MA, USA)로 분석하였다. 분석용 컬럼은 Agilent Zorbax SB-C ${ }_{18}(4.6 \times 250 \mathrm{~mm}, 5 \mu \mathrm{m}$, Agilent Technologies, Palo Alto, CA, USA)를 사용하였고, 이동상 용매는 positive mode에서 $0.1 \%$ formic acid 수용액과 acetonitrile에 용해한 $0.1 \%$ formic acid를 시간에 따라 혼합비율을 조절하면서 분석하 였다. 이동상의 속도는 $0.7 \mathrm{~mL} / \mathrm{min}$, 시료 주입량은 $10 \mu \mathrm{L}$, scan type은 SRM mode로 하였다. SAC(Tokyo Chemical Industry Co., Tokyo, Japan) 표준물질을 시료와 동일한 조건 에서 분석하여 머무름 시간을 비교해 확인하였으며, 각각 의 검량곡선으로부터 그 함량을 산출하였다.

\section{유기산 함량 분석}

각각의 시료를 여과지로 여과한 후 여액을 취하여 0.45 $\mu \mathrm{m}$ membrane filter로 재여과한 다음 $\mathrm{HPLC}$ 로 분석하였다. 분석용 컬럼은 Watchers 120 ODS-BP $(4.6 \times 250 \mathrm{~mm}, 5 \mu \mathrm{m}$, Watchers, Daiso Chemical Co., Tokyo, Japan)를 사용하였고, 이동상 용매는 $0.1 \% \mathrm{H}_{3} \mathrm{PO}_{4}$ 수용액을 $0.5 \mathrm{~mL} / \mathrm{min}$ 의 속도로 주입하였으며, 분석온도는 $30^{\circ} \mathrm{C}$ 를 유지하였고, $10 \mu \mathrm{L}$ 의 시 료를 주입하여 $210 \mathrm{~nm}$ 에서 $\mathrm{UV}$ 검출기를 이용하여 검출하 였다. 총 11종의 유기산(citric acid, oxalic acid, tartaric acid, formic acid, malic acid, glutaric acid, lactic acid, acetic acid, fumatic acid, succinic acid, propionic acid) 표준물질을 시료 와 동일한 조건에서 분석하여 머무름 시간을 비교해 확인하 였으며, 각각의 검량곡선으로부터 그 함량을 산출하였다.

\section{무기물 함량 분석}

무기물은 Lee 등(23)의 방법에 따라 분해용 플라스크에 숙성이 완료된 식초 $1 \mathrm{~g}$ 을 취하여 진한 황산과 진한 질산을 각각 $10 \mathrm{~mL}$ 씩 차례로 가한 다음 heating block에서 무색으로 변할 때까지 분해하였다. 분해하고 남은 여액을 증류수로 $50 \mathrm{~mL}$ 로 정용한 것을 여과한 후 inductively coupled plasma(ICP, Optima 7300DV, Perkin-Elmer Inc., Waltham, $\mathrm{MA}, \mathrm{USA}$ )로 분석하였다. 이 때, RF generator는 $27.12 \mathrm{MHz}$, RF power는 $1300 \mathrm{~W}$, plasma argon $15 \mathrm{~L} / \mathrm{min}$, auxiliary argon flow rate $0.5 \mathrm{~L} / \mathrm{min}$, nebulizer argon flow rate는 $0.8 \mathrm{~L} / \mathrm{min}$, sample up take는 $1.5 \mathrm{~mL} / \mathrm{min}$ 으로 하였다.

\section{결과 및 고찰}

\section{흑마늘 식초 제조를 위한 발효물의 농도}

Table 1은 흑마늘 식초 제조를 위하여 흑마늘과 정제수를 혼합하여 분쇄한 후 동일한 양의 설탕을 보당한 시료액의 농도를 ${ }^{\circ} \mathrm{Brix}$ 로 측정한 결과이다. 흑마늘의 혼합 비율이 높을수록 농도도 높아져 정제수와 흑마늘을 1:2로 혼합하
였을 때 $14{ }^{\circ} \mathrm{Brix}$ 로 가장 농도가 높았고, 1:11로 혼합하였을 때는 $3.5{ }^{\circ} \mathrm{Brix}$ 였다.

이를 이용하여 7일간 알코올 발효 한 후 생성된 알코올의 농도(Table 1)는 흑마늘 혼합물의 농도가 높을수록 더 높아 $3.5{ }^{\circ} \mathrm{Brix}$ 의 일 때 $6 \%$ 의 알코올이 생성되었으며, $14{ }^{\circ} \mathrm{Brix}$ 일 때는 $12 \%$ 의 알코올이 생성되어 초산 발효가 가능한 범위의 알코올이 생성되었음을 확인하였다.

Table 1. Ingredients and mixing conditions for the manufacture of black garlic vinegar

\begin{tabular}{lccccc}
\hline \multicolumn{1}{c}{ Sample code } & BV-3.5 & BV-5 & BV-7 & BV-14 \\
\cline { 2 - 5 } Mixing ratio (Black garlic : Water) & $1: 11$ & $1: 8$ & $1: 5$ & $1: 2$ \\
\hline Mixture concentration ( ${ }^{\circ}$ Brix) & 3.5 & 5 & 7 & 14 \\
Alcohol production volume (\%) & 6 & 7 & 8 & 12 \\
\hline
\end{tabular}

흑마늘 식초의 $\mathrm{pH}$

흑마늘에 물을 혼합해 분쇄하여 $3.5,5,7$ 및 $14{ }^{\circ} \mathrm{Brix}$ 로 농도를 달리하여 제조한 흑마늘 식초의 발효 기간 동안 $\mathrm{pH}$ 의 변화는 Table 2 와 같다. 발효 초기 흑마늘 혼합물의 농도가 가장 높았던 BV-14 시료의 $\mathrm{pH}$ 는 4.42 로 여타 시료 에 비해 유의적으로 낮았으나 발효기간 중 4.60 정도로 높아 졌다가 발효 25 일에는 다시 4.46으로 낮아져 발효 초기에 비해 유의적인 차이가 없었다. 반면 흑마늘 혼합물의 농도 가 $7{ }^{\circ} \mathrm{Brix}$ 이하로 낮았던 여타 실험군의 경우 발효초기 $\mathrm{pH}$ 도 4.6 정도로 높았으며, 발효 9일차에 4.96 5.62의 범위 로 높아졌다가 그 이후부터는 다시 감소하여 발효 25 일에 는 3.85 3.88의 범위였고, 이들 실험군간의 $\mathrm{pH}$ 는 유의적인 차이가 없었다.

Table 2. Changes in the $\mathrm{pH}$ of vinegar supplemented with different amounts of black garlic during fermentation

\begin{tabular}{ccccc}
\hline \multirow{2}{*}{ Sample code } & \multicolumn{4}{c}{ Fermentation period (days) } \\
\cline { 2 - 5 } & 0 & 9 & 18 & 25 \\
\hline BV-3.5 & $4.69 \pm 0.03^{\mathrm{bB1})}$ & $5.62 \pm 0.13^{\mathrm{CD}}$ & $4.63 \pm 0.14^{\mathrm{bB}}$ & $3.87 \pm 0.06^{\mathrm{aA}}$ \\
BV-5 & $4.63 \pm 0.05^{\mathrm{CB}}$ & $5.20 \pm 0.03^{\mathrm{dC}}$ & $4.44 \pm 0.06^{\mathrm{bA}}$ & $3.85 \pm 0.07^{\mathrm{aA}}$ \\
BV-7 & $4.63 \pm 0.03^{\mathrm{bB}}$ & $4.96 \pm 0.14^{\mathrm{CB}}$ & $4.70 \pm 0.16^{\mathrm{bB}}$ & $3.88 \pm 0.08^{\mathrm{aA}}$ \\
BV-14 & $4.42 \pm 0.08^{\mathrm{aA}}$ & $4.64 \pm 0.06^{\mathrm{bA}}$ & $4.60 \pm 0.01^{\mathrm{bB}}$ & $4.46 \pm 0.07^{\mathrm{aB}}$ \\
\hline
\end{tabular}

${ }^{11}$ All values are mean \pm SD $(n=3)$. Means with different superscripts (a-d) within the same row are significantly different $(\mathrm{p}<0.05)$. Means with different superscripts $(\mathrm{A}-\mathrm{D})$ within the same column are significantly different $(\mathrm{p}<0.05)$.

\section{흑마늘 식초의 당도}

흑마늘 식초의 숙성 중 당도의 변화를 분석한 결과는 Table 3 과 같이 발효초기 당도는 $5 \sim 10{ }^{\circ} \mathrm{Brix}$ 로 흑마늘의 첨가량이 많을수록 유의적으로 높았는데, 이는 보당량이 동일하였음을 고려할 때 흑마늘 자체에 포함되어 있는 당분 이 영향을 미쳤기 때문으로 판단된다. 흑마늘 식초의 당도 
는 발효 9일차에 12.00 13.50 ${ }^{\circ} \mathrm{Brix}$ 로 증가하여 이후 발효가 진행되면서 감소하였는데, 숙성이 완료된 발효 25 일에는 5.50 9.50 ${ }^{\circ} \mathrm{Brix}$ 였다.

비타민나무의 잎과 열매를 첨가한 식초에서도 당도는 발효 2 일 경에 $12.4{ }^{\circ} \mathrm{Brix}$ 로 가장 높았다가 발효 기간이 경과함에 따라 감소되는 경향을 나타낸다고 보고되어 있는 데(24) 이는 본 연구의 결과와 유사한 경향이었다.

Table 3. Changes in the sugar content of vinegar supplemented with different amounts of black garlic during fermentation

$\left({ }^{\circ}\right.$ Brix $)$

\begin{tabular}{ccccc}
\hline \multirow{2}{*}{ Sample code } & \multicolumn{4}{c}{ Fermentation period (days) } \\
\cline { 2 - 5 } & 0 & 9 & 18 & 25 \\
\hline BV-3.5 & $5.00 \pm 0.00^{\mathrm{bA} 1)}$ & $12.00 \pm 0.00^{\mathrm{dA}}$ & $4.00 \pm 0.00^{\mathrm{aA}}$ & $5.50 \pm 0.71^{\mathrm{cA}}$ \\
BV-5 & $5.00 \pm 0.00^{\mathrm{abB}}$ & $12.00 \pm 0.00^{\mathrm{CB}}$ & $4.50 \pm 0.71^{\mathrm{aB}}$ & $5.50 \pm 0.71^{\mathrm{bA}}$ \\
BV-7 & $6.00 \pm 0.00^{\mathrm{bC}}$ & $12.50 \pm 0.71^{\mathrm{CB}}$ & $5.00 \pm 0.00^{\mathrm{aC}}$ & $6.50 \pm 0.71^{\mathrm{bB}}$ \\
BV-14 & $10.00 \pm 0.00^{\mathrm{bD}}$ & $13.50 \pm 0.71^{\mathrm{CC}}$ & $7.00 \pm 0.00^{\mathrm{aD}}$ & $9.50 \pm 0.71^{\mathrm{bC}}$ \\
\hline
\end{tabular}

${ }^{1)}$ All values are mean $\pm \mathrm{SD}(\mathrm{n}=3)$. Means with different superscripts (a-d) within the same row are significantly different $(\mathrm{p}<0.05)$. Means with different superscripts $(A-D)$ within the same column are significantly different $(\mathrm{p}<0.05)$.

\section{총 폴리페놀 화합물의 정량}

흑마늘에 물을 가해 $3,6,9$ 및 12 배로 희석한 후 알코올 발효한 다음 초산 발효 기간 동안 식초의 총 폴리페놀 화합 물 함량을 측정한 결과는 Table 4와 같다. 초산발효 전 총 폴리페놀 화합물의 함량은 $19.67 \sim 50.46 \mathrm{mg} / 100 \mathrm{~mL}$ 의 범위 였으며, 흑마늘의 농도가 증가할수록 폴리페놀 화합물의 함량도 증가하였는데, 흑마늘은 생마늘에 비해 약 2.6 배 더 높은 페놀화합물과 5.5 배 더 높은 플라보노이드 화합물 이 함유되어 있다는 보고(25)로 미루어 볼 때 흑마늘 식초 중의 총 폴리페놀 화합물 함량은 흑마늘 원료에서 기인하는 바가 큰 것으로 판단된다.

$\mathrm{Na}$ 등(7)은 감, 무화과, 양조, 쌀 식초의 폴리페놀 함량이 각각 $48.51,32.10,28.41,8.39 \mathrm{mg} / 100 \mathrm{~g}$ 이라고 보고하였으

Table 4. Changes in the total phenolic compound content of vinegar supplemented with different amounts of black garlic during fermentation

\begin{tabular}{ccccc} 
& & & $(\mathrm{mg} / 100 \mathrm{~mL})$ \\
\hline \multirow{2}{*}{ Sample code } & \multicolumn{4}{c}{ Fermentation period (days) } \\
\cline { 2 - 5 } & 0 & 9 & 18 & 25 \\
\hline BV-3.5 & $\left.19.67 \pm 0.59^{\mathrm{bAl}}\right)$ & $14.96 \pm 1.89^{\mathrm{AA}}$ & $13.00 \pm 1.18^{\mathrm{aA}}$ & $20.65 \pm 2.03^{\mathrm{bA}}$ \\
BV-5 & $19.79 \pm 0.00^{\mathrm{bA}}$ & $19.85 \pm 1.62^{\mathrm{BB}}$ & $18.15 \pm 0.74^{\mathrm{aB}}$ & $25.48 \pm 1.33^{\mathrm{CB}}$ \\
BV-7 & $28.10 \pm 0.50^{\mathrm{BB}}$ & $28.31 \pm 0.50^{\mathrm{aC}}$ & $28.58 \pm 0.00^{\mathrm{aC}}$ & $29.38 \pm 0.82^{\mathrm{bC}}$ \\
BV-14 & $50.46 \pm 0.59^{\mathrm{aC}}$ & $56.56 \pm 1.33^{\mathrm{bD}}$ & $56.52 \pm 2.21^{\mathrm{bD}}$ & $52.04 \pm 3.36^{\mathrm{aD}}$ \\
\hline
\end{tabular}

\footnotetext{
${ }^{1)}$ All values are mean $\pm \mathrm{SD}(\mathrm{n}=3)$. Means with different superscripts (a-d) within the same row are significantly different $(\mathrm{p}<0.05)$. Means with different superscripts $(A-D)$ within the same column are significantly different $(\mathrm{p}<0.05)$.
}

며, 감귤 미숙과와 완숙과 식초(26)의 폴리페놀 함량은 각각 $15.47,2.31 \mathrm{mg} / 100 \mathrm{~mL}$, 복분자 식초는 $25.19 \mathrm{mg} / 100 \mathrm{~mL}$ 의 폴리페놀이 함유되어 있다고 보고되어 있다(27). 으름 열매 를 첨가하여 발효한 식초의 총 폴리페놀 함량은 으름 열매 의 첨가량이 증가됨에 따라 유의적으로 증가한다고 보고 (28)되어 있는데, 이들의 연구 결과도 본 연구의 결과와 일치하는 경향이었다.

흑마늘의 첨가 비율을 달리하여 숙성 완료된 식초의 페 놀성 화합물을 정성·정량 분석한 결과는 Table 5 와 같다. 페놀 화합물은 식품 중에 분포도가 높은 총 17 종의 표준물 질과 비교 분석 분석하였으나 pyrogallol과 vanillic acid 2 종 만이 확인되었으며, 총 함량은 BV-14에서 $8.72 \mathrm{mg} / 100 \mathrm{~mL}$ 로 가장 높았다. Pyrogallol의 함량은 $0.17 \sim 0.32 \mathrm{mg} / 100 \mathrm{~mL}$ 로 미량이었으나 vanillic acid는 $5.25 ~ 8.40 \mathrm{mg} / 100 \mathrm{~mL}$ 로 pyrogallol에 비해 약 26배 더 높은 함량이었다. 흑마늘 식초 중의 총 폴리페놀 화합물이 흑마늘 원료에서 기인하고, 정 량된 이들 화합물이 총 폴리페놀 화합물의 17 33\% 정도에 불과한 것으로 볼 때, 아직은 확인되지 않은 페놀성 물질들 도 다수 함유되어 있을 것으로 추정된다.

일반적으로 페놀 화합물은 채소나 과일, 견과류 등에 많 이 들어 있으며(29), 이 중 vanillic acid는 대부분의 페놀 화합물처럼 분자구조상에 수산기 $(\mathrm{OH}-)$ 를 가지고 있어 다 른 화합물과 강한 결합력을 가지며 이러한 결합력에 의하여 항암이나 항균, 항염 등과 같은 다양한 약리활성을 나타내 는 것으로 알려져 있다 $(30,31)$. Pyrogallolo은 흰색의 바늘 모양의 결정구조를 지니는 polyphenol계 화합물로서 공기 나 알칼리성 용액 중에서 쉽게 산화되기 때문에 환원제로서 사용되며, $\mathrm{Sb}, \mathrm{Bi}$ 등의 분석, 금, 은, 수은 등의 정량시의 환원제 등으로 사용하고 항균, 항산화 등에 효과가 있다 $(32,33)$.

Table 5. Phenolic compound contents black garlic vinegar fermented for 25 days

\begin{tabular}{cccc} 
& \multicolumn{3}{c}{ Phenolic compounds } \\
\hline \multirow{2}{*}{ Samples code } & Pyrogallol & Vanillic acid & Total \\
\cline { 2 - 4 } & $0.22 \pm 0.00^{\mathrm{bl}}$ & $6.50 \pm 0.04^{\mathrm{b}}$ & 6.72 \\
\hline BV-3.5 & $0.20 \pm 0.00^{\mathrm{b}}$ & $5.25 \pm 0.54^{\mathrm{a}}$ & 5.45 \\
BV-5 & $0.17 \pm 0.01^{\mathrm{a}}$ & $5.52 \pm 0.03^{\mathrm{a}}$ & 5.69 \\
BV-7 & $0.32 \pm 0.01^{\mathrm{c}}$ & $8.40 \pm 0.45^{\mathrm{c}}$ & 8.72 \\
BV-14
\end{tabular}

${ }^{1)}$ All values are mean $\pm \mathrm{SD} \quad(\mathrm{n}=3)$. Means with different superscripts $(\mathrm{a}-\mathrm{c})$ within the same column are significantly different $(\mathrm{p}<0.05)$.

\section{S-allyl cysteine(SAC) 함량}

흑마늘의 첨가 비율을 달리하여 발효한 식초의 SAC 함 량을 분석한 결과는 Table 6과 같다. 초산균을 접종한 직후 $\mathrm{BV}-3.5$ 와 BV-5에서는 SAC가 검출되지 않았으나 BV-7에 
서는 $1.12 \mathrm{mg} / \mathrm{L}, \mathrm{BV}-14$ 에서는 $13.12 \mathrm{mg} / \mathrm{L}$ 가 검출되어 흑마 늘의 첨가량에 따라 그 함량에 차이가 컸다. 발효 9일에 유의적으로 그 함량이 증가하였으나 그 이후부터는 유의적 인 변화가 없어 발효 초기와 유사한 범위였다.

$\mathrm{SAC}$ 는 항암, 항당뇨, 항산화, 면역증강, 항동맥경화, 항 혈전, 항고혈압, 뇌신경세포보호 등의 효능을 나타낸다고 보고되어 있다(34). Jung 등(35)은 유산균 발효마늘 추출물 들 중 SAC의 함량이 발효하지 않은 대조구에 비하여 4 배 정도 높은 함량을 나타내었다고 보고 한 바 있으며, probiotics를 이용하여 발효한 흑마늘의 SAC를 분석한 결과 발효기간이 경과할수록 증가한다는 보고도 있다(36). 본 실험의 결과에서는 발효 기간 중 $\mathrm{SAC}$ 함량은 불규칙한 증감을 보였으나 발효 전에 비해 발효 완료 후에는 유의적 인 차이가 없어 이들 결과들과 상이한 경향이었는데, 이는 유산균과 초산균의 발효특성 차이에 따른 것으로 추정된 다.

Table 6. Changes in the S-allyl cysteine contents of vinegar supplemented with different amounts of black garlic during fermentation

$(\mathrm{mg} / \mathrm{L})$

\begin{tabular}{ccccc}
\hline \multirow{2}{*}{ Sample code } & \multicolumn{4}{c}{ Fermentation period (days) } \\
\cline { 2 - 5 } & 0 & 9 & 18 & 25 \\
\hline BV-3.5 & $\mathrm{ND}^{1)}$ & $\mathrm{ND}$ & $\mathrm{ND}$ & $\mathrm{ND}$ \\
BV-5 & $\mathrm{ND}$ & $\mathrm{ND}$ & $\mathrm{ND}$ & $\mathrm{ND}$ \\
BV-7 & $1.12 \pm 0.05^{\mathrm{a} 2}$ ) & $2.74 \pm 0.36^{\mathrm{bA}}$ & $1.72 \pm 0.05^{\mathrm{aA}}$ & $1.51 \pm 0.16^{\mathrm{aA}}$ \\
BV-14 & $13.12 \pm 0.99^{\mathrm{aB}}$ & $17.56 \pm 1.04^{\mathrm{bB}}$ & $13.44 \pm 0.22^{2^{\mathrm{B}}}$ & $14.18 \pm 0.95^{\mathrm{aB}}$ \\
\hline
\end{tabular}

${ }^{1)} \mathrm{ND}$, not detected.

${ }^{2)}$ All values are mean $\pm S D(n=3)$. Means with different superscripts $(a-b)$ within the same row are significantly different $(\mathrm{p}<0.05)$. Means with different superscripts $(\mathrm{A}-\mathrm{B})$ within the same column are significantly different $(\mathrm{p}<0.05)$.

\section{유기산 함량}

식초에 있어서 양조과정 중 생성되는 유기산은 초산균의 작용으로 생성되는 초산이 대부분이며 이는 품질 판정에 중요한 성분의 하나로 일반적으로 국내 식초 규격은 초산 함량을 4 20\%으로 규정하고 있다(37).

흑마늘의 첨가비율을 달리하여 제조한 식초의 발효기간 중 유기산 함량변화를 측정한 결과는 Table 7과 같다. 총 11 종의 유기산을 분석한 결과 흑마늘 식초에서는 lactic acid, acetic acid, citric acid, succinic acid 및 propionic acid 5 종의 유기산이 검출되었다. 유기산의 종류에 따라 발효 기간별 함량의 변화 양상이 서로 상이하였는데, lactic acid 는 발효 초기에 129.96 868.48 mg/100 mL이었다가 발효 18 일에 $511.68 \sim 793.32 \mathrm{mg} / 100 \mathrm{~mL}$ 로 가장 높았고 그 이후에 는 감소하여 $100.45 \sim 396.12 \mathrm{mg} / 100 \mathrm{~mL}$ 이었다. Acetic acid 는 발효 초기 $888.03 ~ 1477.39 \mathrm{mg} / 100 \mathrm{~mL}$ 이는데, 발효가 진행될수록 그 함량은 증가하는 경향을 보였고 발효 25 일
에는 4208.90 5570.29 mg/100 mL로 가장 높은 함량이었다. Citric acid는 발효 9일에 $149.72 ~ 688.60 \mathrm{mg} / 100 \mathrm{~mL}$ 로 시료 간에 5 배 정도의 함량 차이를 보였는데, 흑마늘 첨가량이 많을수록 그 함량이 더 높았다. Succinic acid 및 propionic acid도 citric acid와 동일한 경향으로 발효기간 중 불규칙한 증감을 보였으나 발효 25 일 후에는 흑마늘의 첨가량이 높 을수록 그 함량도 높았다.

$\mathrm{Yi}$ 등(26)의 연구에서 감귤 미숙과즙의 첨가비율을 30 , $35,40 \%$ 로 달리하여 제조한 식초의 유기산으로는 lactic acid와 acetic acid가 다량 검출되었다고 보고한 바 있는데, 본 연구결과에서 흑마늘 식초의 주요 유기산은 acetic acid 로 월등히 함량이 높으며, 그 외 유기산들의 함량은 대차를 보이지 않았다. Lactic acid의 함량이 높을 경우 이취의 원인 이 되기도 하는데(38), 이는 초산발효의 진행과정에서 균주 의 사멸기 동안 공급되는 영양분이 불충분하여 acetic acid 대신 부산물로 lactic acid가 생성되거나(39), 발효 초기 젖산 균이 생육하여 lactic acid를 생성하였기 때문이라고 알려져 있다(40). 본 연구에서는 초산발효 진행이 원활하여 acetic acid를 제외한 유기산의 함량은 유사한 범위였고, 흑마늘의 첨가 비율이 너무 낮거나 높은 경우 오히려 초산균의 생육 이 저해됨을 확인할 수 있었다.

\section{무기물 함량}

흑마늘의 첨가량과 초기 알코올 함량을 달리하여 25 일간 초산 발효한 후 무기물 함량을 분석하였다(Table 8). 총 8 종 $(\mathrm{K}, \mathrm{Fe}, \mathrm{Mg}, \mathrm{Zn}, \mathrm{P}, \mathrm{Na}, \mathrm{Ca}$ 및 $\mathrm{Mn})$ 의 무기물이 검출되었으며, 흑마늘 첨가량이 가장 많은 BV-14군에서 전체 무기물 함량 이 $2,369.08 \mathrm{mg} / \mathrm{L}$ 로 가장 높았다. 흑마늘 첨가량이 가장 적었던 BV-3.5군에서 $602.71 \mathrm{mg} / \mathrm{L}$ 로 무기물의 총량이 가장 적어 흑마늘의 첨가량과 무기물의 총량은 비례하였는데, 이를 통해 흑마늘 식초 중의 무기물은 흑마늘 자체에 함유 되어 있던 것이 그대로 용출된 것으로 판단된다.

흑마늘의 첨가량 따라 차이가 있지만 모든 시료에서 $\mathrm{K}$ $>\mathrm{P}>\mathrm{Mg}>\mathrm{Ca}>\mathrm{Na}>\mathrm{Zn}>\mathrm{Mn}>\mathrm{Fe}$ 순으로 많이 함유되어 있었는데, 가장 함량이 높은 $\mathrm{K}$ 은 전체 무기물 함량 대비 60.8 68.4\%를 점유하고 있었고 두 번째로 높은 $\mathrm{P}$ 은 25.7 26.0\% 범위로 이들 무기물이 전체의 $85 \%$ 이상을 점유 하고 있었다. 함량이 가장 낮았던 $\mathrm{Fe}$ 의 경우 흑마늘 첨가량 이 낮은 시료에서는 검출되지 않았으며, 흑마늘 함량이 높 았던 BV-14군에서도 $0.55 \mathrm{mg} / \mathrm{L}$ 로 미량 함유되어 있었다.

흑마늘 중의 무기물은 $\mathrm{K}$ 와 $\mathrm{P}$ 이 전체 무기물의 $80 \%$ 이상 을 점유하고 있으며 다음으로 $\mathrm{Mg}$ 과 $\mathrm{Ca}$ 의 순이라고 보고 (41)되어 있는데, 이는 본 연구의 흑마늘 식초 중 무기물 함량과 동일한 경향으로, 흑마늘의 무기물이 식초 중으로 대부분 이행되었음을 다시 확인할 수 있었다.

Woo 등(42)은 참다래 식초에서 무기물은 $\mathrm{K}$ 이 가장 높고, 다음으로 $\mathrm{Na}, \mathrm{Ca}, \mathrm{Mg}, \mathrm{P}$ 의 순이라고 하였으며, Hong 등(43) 
은 오이식초의 무기물은 $\mathrm{K}$ 의 함량이 가장 높고, 다음으로 $\mathrm{Mg}, \mathrm{Ca}$ 및 $\mathrm{Na}$ 의 순이었고, $\mathrm{Fe}, \mathrm{Mn}$ 및 $\mathrm{Cu}$ 는 미량 함유되어 있었다고 보고한 바 있다. 현미식초에서도 높게 발현되는 무기물 성분이 $\mathrm{K}$ 과 $\mathrm{P}$ 이라는 보고(44)도 있어 식초의 주요 무기물은 $\mathrm{K}$ 이며, 발효시 첨가되는 재료에서 기인하므로 재료의 종류나 특성에 따라 무기물의 조성이 서로 상이한 것으로 생각된다.
흑마늘 식초를 25 일간 초산발효 시키면서 발효과정 중 품 질특성 분석을 위해 관련인자를 분석하였다. $\mathrm{pH}$ 는 발효 중 점차 감소하여 25일 후에 3.85 4.46였고, 당도는 발효 9일 후에 $12.00 \sim 13.50{ }^{\circ} \mathrm{Brix}$ 로 가장 높았으나 이후 다시 감소하여 발효초기와 유사한 범위였다. 총 폴리페놀 화합 물 함량은 발효 0일차에 $19.67 \sim 50.46 \mathrm{mg} / 100 \mathrm{~mL}$ 이던 것이 최종 25 일에는 $20.65 ~ 52.04 \mathrm{mg} / 100 \mathrm{~mL}$ 의 범위로 미량 증가

Table 7. Changes in the organic acid contents of vinegar supplemented with different levels amounts of black garlic during fermentation

\begin{tabular}{|c|c|c|c|c|c|c|c|}
\hline Sample code & Fermentation period (days) & Lactic acid & Acetic acid & Citric acid & Succinic acid & Propionic acid & Total \\
\hline \multirow{4}{*}{ BV-3.5 } & 0 & $129.96 \pm 0.17^{\mathrm{aAl})}$ & $888.03 \pm 1.68^{\mathrm{aA}}$ & $111.12 \pm 0.01^{\mathrm{bA}}$ & $70.86 \pm 1.04^{\mathrm{bA}}$ & $93.42 \pm 0.49^{\mathrm{bA}}$ & $1,293.39$ \\
\hline & 9 & $94.26 \pm 0.15^{\mathrm{aA}}$ & $1309.35 \pm 0.72^{\mathrm{bA}}$ & $149.72 \pm 0.20^{\mathrm{cA}}$ & $104.91 \pm 0.01^{\mathrm{cA}}$ & $86.44 \pm 1.58^{\mathrm{aA}}$ & $1,744.68$ \\
\hline & 18 & $512.89 \pm 8.57^{\mathrm{bA}}$ & $1463.14 \pm 1.55^{\mathrm{cB}}$ & $88.75 \pm 0.11^{\mathrm{aA}}$ & $21.19 \pm 9.68^{\mathrm{aA}}$ & $107.48 \pm 3.43^{\mathrm{cA}}$ & $2,193.45$ \\
\hline & 25 & $100.45 \pm 0.15^{\mathrm{aA}}$ & $4828.11 \pm 1.15^{\mathrm{dB}}$ & $153.06 \pm 0.27^{\mathrm{dA}}$ & $136.10 \pm 0.29^{\mathrm{dA}}$ & $109.62 \pm 1.31^{\mathrm{cA}}$ & $5,327.34$ \\
\hline \multirow{4}{*}{ BV-5 } & 0 & $188.53 \pm 1.10^{\mathrm{cB}}$ & $1144.31 \pm 5.40^{\mathrm{aB}}$ & $190.25 \pm 0.23^{\mathrm{cB}}$ & $87.15 \pm 1.19^{\mathrm{bB}}$ & $123.75 \pm 9.95^{\mathrm{aA}}$ & $1,733.99$ \\
\hline & 9 & $123.98 \pm 0.44^{\mathrm{aB}}$ & $1641.00 \pm 4.56^{\mathrm{bC}}$ & $204.11 \pm 1.39^{\mathrm{dB}}$ & $146.21 \pm 0.10^{\mathrm{cB}}$ & $118.62 \pm 1.73^{a B}$ & $2,233.92$ \\
\hline & 18 & $793.32 \pm 1.79^{\mathrm{dB}}$ & $1726.43 \pm 1.76^{\mathrm{B}}$ & $152.49 \pm 5.24^{a \mathrm{~B}}$ & $18.73 \pm 1.28^{\mathrm{aA}}$ & $127.73 \pm 0.72^{\mathrm{aA}}$ & $2,818.70$ \\
\hline & 25 & $128.96 \pm 0.31^{\mathrm{bB}}$ & $5570.29 \pm 2.60^{\mathrm{dD}}$ & $182.32 \pm 0.27^{6 \mathrm{~B}}$ & $145.09 \pm 1.65^{c B}$ & $132.05 \pm 2.53^{a B}$ & $6,158.71$ \\
\hline \multirow{4}{*}{ BV-7 } & 0 & $330.02 \pm 1.06^{\mathrm{CC}}$ & $1477.39 \pm 0.71^{\mathrm{aC}}$ & $273.78 \pm 0.27^{\mathrm{bC}}$ & $103.49 \pm 2.00^{\mathrm{bC}}$ & $184.78 \pm 1.78^{a B}$ & $2,369.46$ \\
\hline & 9 & $187.87 \pm 1.04^{\mathrm{aC}}$ & $2316.48 \pm 3.33^{\mathrm{bC}}$ & $319.62 \pm 1.72^{\mathrm{dC}}$ & $217.64 \pm 1.53^{\mathrm{dC}}$ & $176.38 \pm 1.79^{\mathrm{aC}}$ & $3,217.99$ \\
\hline & 18 & $578.83 \pm 0.96^{\mathrm{dA}}$ & $2459.99 \pm 7.01^{c D}$ & $238.19 \pm 1.47^{7 \mathrm{C}}$ & $53.16 \pm 1.02^{\mathrm{aB}}$ & $214.78 \pm 16.10^{\mathrm{bB}}$ & $3,544.95$ \\
\hline & 25 & $211.10 \pm 0.19^{\mathrm{bC}}$ & $5434.67 \pm 1.26^{\mathrm{dC}}$ & $302.06 \pm 0.52^{{ }^{C}}$ & $147.25 \pm 2.78^{\mathrm{cB}}$ & $212.56 \pm 4.17^{\mathrm{bC}}$ & $6,307.64$ \\
\hline \multirow{4}{*}{ BV-14 } & 0 & $868.48 \pm 4.90^{\mathrm{dD}}$ & $1227.38 \pm 5.74^{\mathrm{aA}}$ & $358.74 \pm 5.15^{\mathrm{aD}}$ & $150.91 \pm 0.26^{\mathrm{aD}}$ & $397.80 \pm 21.75^{\mathrm{aC}}$ & $3,003.31$ \\
\hline & 9 & $352.60 \pm 7.81^{\mathrm{aD}}$ & $2092.06 \pm 6.69^{\mathrm{bD}}$ & $688.60 \pm 3.87^{d D}$ & $420.58 \pm 0.96^{\mathrm{dD}}$ & $377.98 \pm 1.74^{\mathrm{aD}}$ & $3,931.82$ \\
\hline & 18 & $511.68 \pm 3.25^{\mathrm{cA}}$ & $3884.20 \pm 2.24^{\mathrm{cA}}$ & $525.99 \pm 0.87^{\mathrm{CD}}$ & $164.91 \pm 1.08^{\complement C}$ & $445.85 \pm 7.77^{\mathrm{bC}}$ & $5,532.63$ \\
\hline & 25 & $396.12 \pm 1.51^{\mathrm{bD}}$ & $4208.90 \pm 1.48^{\mathbb{d D}}$ & $381.96 \pm 1.31^{6 D}$ & $160.20 \pm 0.17^{\mathrm{bC}}$ & $384.10 \pm 4.82 \mathrm{aD}$ & $5,531.28$ \\
\hline
\end{tabular}

${ }^{11}$ All values are mean $\pm \mathrm{SD}(\mathrm{n}=3)$. Means with different superscripts (a-d) within the same row are significantly different $(\mathrm{p}<0.05)$. Means with different superscripts $(\mathrm{A}-\mathrm{D})$ within the same column are significantly different $(p<0.05)$.

Table 8. Mineral contents of black garlic vinegar fermented for 25 days

$(\mathrm{mg} / \mathrm{L})$

\begin{tabular}{cccccccccc}
\hline \multirow{2}{*}{ Samples code } & \multicolumn{9}{c}{ Minerals } \\
\cline { 2 - 10 } & $\mathrm{K}$ & $\mathrm{Fe}$ & $\mathrm{Mg}$ & $\mathrm{Zn}$ & $\mathrm{P}$ & $\mathrm{Na}$ & $\mathrm{Ca}$ & $\mathrm{Mn}$ & Total \\
\hline BV-3.5 & $366.23 \pm 2.84^{\mathrm{al})}$ & $\mathrm{ND}^{2)}$ & $26.33 \pm 3.24^{\mathrm{a}}$ & $1.17 \pm 0.09^{\mathrm{a}}$ & $156.90 \pm 1.41^{\mathrm{a}}$ & $15.59 \pm 2.16^{\mathrm{a}}$ & $36.40 \pm 17.73^{\mathrm{a}}$ & $0.08 \pm 0.03^{\mathrm{a}}$ & 602.71 \\
BV-5 & $478.30 \pm 5.37^{\mathrm{b}}$ & $\mathrm{ND}$ & $42.26 \pm 1.27^{\mathrm{b}}$ & $2.21 \pm 0.63^{\mathrm{b}}$ & $200.63 \pm 0.85^{\mathrm{b}}$ & $24.35 \pm 1.98^{\mathrm{b}}$ & $33.45 \pm 1.75^{\mathrm{a}}$ & $0.18 \pm 0.02^{\mathrm{b}}$ & 781.38 \\
BV-7 & $760.13 \pm 9.98^{\mathrm{c}}$ & $0.10 \pm 1.05^{\mathrm{a}}$ & $65.28 \pm 1.53^{\mathrm{c}}$ & $1.77 \pm 0.77^{\mathrm{ab}}$ & $289.83 \pm 1.88^{\mathrm{c}}$ & $26.89 \pm 3.23^{\mathrm{b}}$ & $52.20 \pm 5.18^{\mathrm{a}}$ & $0.38 \pm 0.01^{\mathrm{c}}$ & $1,196.60$ \\
BV-14 & $1619.67 \pm 14.52^{\mathrm{d}}$ & $0.55 \pm 1.13^{\mathrm{a}}$ & $104.75 \pm 4.24^{\mathrm{d}}$ & $2.25 \pm 0.11^{\mathrm{b}}$ & $556.70 \pm 6.16^{\mathrm{d}}$ & $35.91 \pm 3.45^{\mathrm{c}}$ & $48.34 \pm 5.76^{\mathrm{a}}$ & $0.92 \pm 0.03^{\mathrm{d}}$ & $2,369.08$ \\
\hline
\end{tabular}

${ }^{11}$ All values are mean $\pm \mathrm{SD}(\mathrm{n}=3)$. Means with different superscripts (a-d) within the same column are significantly different $(\mathrm{p}<0.05)$.

${ }^{2)} \mathrm{ND}$, not detected.

\section{요 약}

흑마늘에 가수량을 달리하여 $3,6,9$ 및 12 배가 되도록하 여 알코올 발효시켜 초기 알코올 농도를(6 12\%)로 달리한
하였다. 최종 숙성 완료된 흑마늘 식초에서 페놀화합물을 확인 동정한 결과 pyrogallol과 vanilic acid가 검출되었으며, 흑마늘의 농도가 높을수록 그 함량이 더 높았다. S-allyl cysteine(SAC) 함량은 6배 이상으로 가수희석된 흑마늘 식 
초에서는 검출되지 않았고, 흑마늘의 첨가량에 비례하여 그 함량이 높았는데 발효 기간에 따른 함량의 차이는 적었 다. 유기산은 총 5 종이 검출되었는데, 검출된 유기산 중 acetic acid의 함량이 가장 높아 발효가 완료된 25 일차 시료 에서 4,208.90 5,570.29 mg/100 mL이었고 유기산의 총량은 $5,327.34 \sim 6,307.64 \mathrm{mg} / 100 \mathrm{~mL}$ 의 범위였다. 발효 25일 후 흑마늘 식초의 무기물 함량은 K이 $366.23 ~ 1619.67 \mathrm{mg} / \mathrm{L}$ 로 가장 높았고, 흑마늘의 첨가량이 높을수록 총 함량이 더 높았다.

\section{감사의 글}

본 연구는 산업통상자원부 지역특화산업육성사업기술 개발사업(과제번호:R0003466)성과의 일부이며 지원에 감 사드립니다.

\section{References}

1. Adams MR (1998) Vinegar In: Microbiology of fermented food. Blackie Academic and Professional, London, UK, p 1-44

2. Kim MJ, Choi JH, Kwon SH, Kim HD, Bang MH, Yang SA (2013) Characteristics of fermented dropwort extract and vinegar using fermented dropwort extract and its protective effects on oxidative damage in rat glioma C6 cells. Korean J Food Sci Technol, 45, 350-355

3. Jeong YJ, Lee MH (2000) A view and prospect of vinegar using kyungpook speccial products (persimmon, apple and vinegar). Food Ind Nutr, 5, 53-59

4. Baek CH, Jeong DH, Baek SY, Choi JH, Park HY, Choi HS, Jeong ST, Kim JH, Jeong YJ, Kwon JH, Yeo SH (2013) Quality characteristics of farm-made brown rice vinegar via traditional static fermentation. Korean J Food Preserv, 20, 564-572

5. Ann YG, Kim SK, Shin CS (2001) Studies on wax gourd - ginseng vinegar. Korean J Food Nutr, 14, 52-58

6. Seo HB, Song YJ, Kang JY, Kwon DK, Kim PG, Ryu SP (2011) The study of persimmon vinegar as a functional drink on reduce blood lipids and enhance exercise perfomance. J Korean For Soc, 100, 232-239

7. Na HS, Choi GC, Yang SI, Lee JH, Cho JY, Ma SJ, Kim JY (2013) Comparison of characteristics in commercial fermented vingars made with different ingredients. Korean J Jood Preserv, 20, 482-487

8. Hong SM, Moon HS, Lee JH, Lee HI, Jeong JH, Lee
MK, Seo KI (2012) Development of functional vinegar by using cucumbers. J Korean Soc Food Sci Nutr, 41, 927-935

9. Cho JG (2008) Garlic and health. Food Preserv Proces Ind, 7, 2-8

10. Jeong DH, Jeong SO (2005) Garlic science. World science, Seoul, Korea, p 6

11. Bakri IM, Douglas CWI (2005) Inhibitory effect of garlic extract on oral bacteria. Arch Oral Biol, 50, 645-651

12. Clement F, Pramod SN, Venkatesh YP (2010) Identity of the immunomodulatory proteins from garlic (Allium sativum) with the major garlic lectins or agglutinins. Int Immunopharmacol, 10, 316-324

13. Pedraza-Chaverri J, Medina-Campos ON, Avila-Lombardo R, Berenice Zuniga-Bustos A, Orozco-Ibarra M (2006) Reactive oxygen species scavenging capacity of different cooked garlic preparation. Life Sci, 78, 761-770

14. Rose P, Whiteman M, Moore PK, Zhu YZ (2005) Bioactive S-alk(en)yl cysteine sulfoxide metabolites in the genus Allium: the chemistry of potential therapeutic agents. Nat Prod Rep, 22, 51-68

15. Bae SE, Cho SY, Won DY, Lee SH, Park HJ (2012) A comparative study of the different analytical methods for analysis of S-allyl cysteine in black garlic by HPLC. LWT-Food Sci Technol, 46, 532-535

16. Nagatoshi I, Benjamin HS, Kenjiro R, Hiromichi M, Yoichi I (1999) Antioxidant effects of fructosyl arginine, a maillard reaction product in aged garlic extract. J Nutr Biochem, 10, 373-376

17. Min JS, Kang BW, Park JU, Kim MJ, Lee HH, Ryu EJ, Joo WH, Kim KH, Jeong YK (2013) Effect of black garlic extract on cytokine generation of mouse spleen cells. J Life Sci, 23, 63-68

18. Kim GH, Kim JH, Yang JY (2014) Change in flavor components of black-fermented garlic wine according to the type of chips during the manufacturing process. J Food Hyg Safety, 29, 73-77

19. Park CH, Kim KH, Kim NY, Kim SH, Yook HS (2014) Antioxidative capacity and quality characteristics of yanggaeng with fermented aged black giant garlic (Allium ampeloprasum L., var. ampeloprasum auct.) paste. Korean J Food Nutr, 27, 1014-1021

20. Sim HJ, Hwang CR, Kang MJ, Kim GM, Shin JH (2014) The quality and sensory characteristics of tofu with various levels of balck garlic extract. Korean J Food Preserv, 21, 688-693

21. Jeong TS, Kim JH, An SA, Won YD, Lee SH (2013) 
Effect of black garlic on antioxidant activity and amino acids composition in Cheonggukjang. Korean J Food Preserv, 20, 643-649

22. Folin O, Denis W (1915) A colorimetric method for determination of phenols (phenol derivatives) in urine. J Biol Chem, 22, 305-308.

23. Lee SJ, Ryu JH, Kim RJ, Lee HJ, Sung NJ (2010) Effect of removed peel from sweet persimmon on nutritional ingredients and antioxidant activities. J Korean Soc Food Sci Nut, 39, 1495-1502

24. Yoon JR, Chang YH (2014) Quality characteristics of vinegar added with sea buckthorn (Hippophae rhamnoides) leaf extract and berry juice by different fermentation methods. Ph D Thesis, Myongji University, Korea, p 178

25. Choi DJ, Lee SJ, Kang MJ, Cho HS, Sung NJ, Shin JH (2008) Physicochemical characteristics of black garlic (Allium sativum L.). J Korean Soc Food Sci Nutr, 37, 465-471

26. Yi MR, Hwang JH, Oh YS, Oh HJ, Lim SB (2014) Quality characteristics and antioxidant activity of immature Citrus unshiu vinegar. J Korean Soc Food Sci Nutr, 43, 250-257

27. Hong SM, Kang MJ, Lee JH, Jeong JH, Kwon SH, Seo KI (2012) Production of vinegar using Rubus coreanus and its antioxidant activities. Korean J Food Preserv, 19, 594-603

28. Lee JC, Han WC, Lee JH, Jang KH (2012) Quality evaluation of vinegar manufactured using rice and Rosa rugosa Thunb. Korean J Food Sci Technol, 44, 202-206

29. Murota K, Terao J (2003) Antioxidative flavonoid quercetin : implication of its intestinal absorption and metabolism. Arch Biochem Biophys, 417, 12-17

30. Mei Y, Wei D, Liu J (2003) Reversal of cancer mutidrug resistance by tea polyphenol in KB cells. J Chemother, $15,260-265$

31. Ha DH, Choi TJ, Yoo SM (2007) Effects of vanillic acid on the cell viability and melanogenesis in cultured human skin melanoma cells damaged by ROS-induced cytotoxicity. J Exp Biomed Sci, 13, 349-354

32. Kim KJ, Do JR, Jo JH, Kim YM, Kim BS, Lim SD, Kang SN (2005) Antibacterial activity of Terminalia chebula Retz. extract against food spoilage microorganisms.
Korean J Food Sci Technol, 37, 498-503

33. Malcolm D, Elliott KAC (1930) The use of barcroft apparatus for the measurement of tissue respiration. Biochem J, 24, 820-833

34. Amagase $\mathrm{H}$ (2006) Clarifying the real bioactive constituents of garlic. J Nutr, 136, 716-725

35. Jung EB, Choi JH, Yu HJ, Kim KH, Lee SK, Hwang YI, Lee SH (2013) Organosulfur compounds in fermented garlic extracts and the effects on alcohol induced cytotoxicity in CYP2E1-transfected HepG2 cells. J Korean Soc Food Sci Nutr, 42, 342-347

36. Tak HM, Kim GM, Hwang CR, Kang MJ, Shin JH (2014) Quality characteristics and biological activity of fermented black garlic with probiotics. J Life Sci, 24, 549-557

37. Ko EJ, Hur SS, Choi YH (1998) The establichment of optimum cultural conditions for manufacturing garlic vinegar. J Korean Soc Food Sci Nutr, 27, 102-108

38. Woo CH, Park CH, Yoon HH (2000) Production of acetic acid from cellulosic biomass. Korean J Biotechnol Bioeng, 15, 458-463

39. Yoon SR, Kim GR, Lee JH, Lee SW, Yeo SH, Jeong YJ, Kwon JH (2010) Properties of organic acids and volatile components in brown rice vinegar prepared using different yeasts and fermentation methods. Korean J Food Preserv, 17, 733-740

40. Isuzugawa K, Ogihara Y, Inoue M (2001) Different generation of inhibitons against gallic acid induced apoptosis produces different sensitivity to gallic acid. Biol Pharm Bull, 24, 249-353

41. Woo SM, Kim OM, Choi IW, Kim YS, Choi HD, Jeong YJ (2007) Condition of acetic acid fermentation and effect of oligosaccharide addition on kiwi vinegar. Korean $\mathbf{J}$ Food Preserv, 14, 100-104

42. Hong SM, Moon HS, Lee JH, Lee HI, Jeong JH, Lee MK, Seo KI (2012) Development of functional vinegar by using cucumbers. J Korean Soc Food Sci Nutr, 41, 927-935

43. Joo KH, Cho MH, Park KJ, Jeong SW, Lim JH (2009) Effects of fermentation method and brown rice content on quality characteristics of brown rice vinegar. Korean J Food Preserv, 16, 33-39 